\title{
Animal Cruelty and Intimate Partner Homicide in Edgar Allan Poe's "The Black Cat"
}

\author{
Afra S. Alshiban \\ Al Imam Mohammad Ibn Saud University
}

\begin{abstract}
The relation between animal maltreatment and interpersonal violence has long been of interest to developmental psychologists, psychiatrists, law enforcement officials, criminologists, and others from related disciplines who concluded that the motivation behind these atrocities is a deep-seated need for power and control that stems from inadequacy. The culprit begins by practising on animals, before graduating to humans, mainly women. In 1843, Edgar Allan Poe saw the potential significance of cruelty to animals as a precursor to future violence against humans and brought it to life through his short story "The Black Cat." The narrator begins his reign of terror by practising on cats (women stand-ins) until he summons enough courage to murder the real source of his misery-his spouse. The story is artistically coherent if understood in terms of cruelty to animals as an unfavourable prognostic sign characteristic of those who will kill. Until now, animal cruelty in Poe's tale received relatively little attention from literary critics. To date, no inquiry has put forward a theory regarding the abuse of animals and its relation to homicide. Hence, this study proposes to look into this disturbing phenomenon and to complement the Poe scholarship.
\end{abstract}

Keywords: Poe, animal cruelty, interpersonal violence, projection, cats, women, homicide.

\section{Introduction:}

In 1964 convicted serial killer Albert De Salvo, "The Boston Strangler," confessed to torturing and killing cats before graduating to humans - mostly women. He was quoted as saying of felines in general:

I don't like cats ... I used to shoot cats with a bow and arrow, put it right through their belly, and sometimes they ran with the arrow right through them, yowling, and I don't recall being too upset by that. . . . Sometimes when I would see them, before the shoot, I'd get such a feeling of anger that I think I could tear those cats apart with my bare hands. I don't understand this, but just that I hated them and they had done nothing to me. (qtd. in Rae, 1967, 61)

De Salvo's case proves eerily similar to the case Poe (1809-1849) presents through his short story "The Black Cat" (1843), where a seemingly docile husband begins his reign of terror, first, by killing the family cat, then, by butchering his wife. Poe's narrator, like De Salvo, also cannot understand his intense hatred of cats. Moreover, like De Salvo, he too progresses to killing women. On the eve of his execution, he confesses his felonies. He begins by describing himself as a kind, affectionate man, who loved animals to the extent of keeping a menagerie of pets. He had "birds, gold-fish, a fine dog, rabbits, a small monkey, and a cat" (Poe, 1843, 531). One day, in a fit of rage after a night of heavy drinking, he attacks his beloved cat, Pluto, by cutting out its eye with a penknife; a few days later he hangs it. Each act of cruelty satiates him only temporarily, for soon the urge to kill returns and he finds himself unable to resist the compulsion. In his frenzy, he attacks and kills 
his wife, is apprehended by police, arrested, and sentenced to death.

What makes "The Black Cat" compelling is the way in which the narrator tells his tale with clinical impartiality. The speaker proclaims, "I am above the weakness of seeking to establish a sequence of cause and effect, between the disaster and the atrocity. But I am detailing a chain of facts - and wish not to leave even a possible link imperfect" (Poe, 1843, 533). In these lines, it is not difficult to detect the indirect confession of inadequacy and to trace his psychological process. Insisting on his rationality, he explains that alcoholism causes "the change in [his] disposition." And adds, "for what disease is like Alcohol!" (Poe, 1843, 532). Still, as the story unfolds it becomes evidently clear that his problem is not with alcohol, nor is it with animals (cats in particular), but with women instead.

The cruel treatment of animals in Poe's tale has received relatively little attention from literary critics. To date, no inquiry has put forward a full-fledged theory regarding animal abuse and its relation to intimate partner homicide. Consequently, this study examines "The Black Cat" primarily from the criminological and psychological line of reasoning on the link between animal abuse and violence against humans. Experts in both fields are in unanimity that animal abuse is a realized sadistic fantasy. The perpetrator begins by fantasizing about killing animals then escalates the fantasy to killing humans. The criminal psychologist Ressler maintains that "animal cruelty, like rape and sexual homicide, is often motivated by a need for power and control gained at the expense of a relatively vulnerable victim" (Ressler, 1988, 177).

In 1843, Poe saw the potential significance of cruelty to animals as an early indicator of problems of power and control and acts of retaliation. His narrator fixates on cats until finally summoning enough courage to murder his wife. This seems to be of overwhelming significance from both a criminological and a psychological perspective. Feminist philosophy further applies to the story given that feminist views have been instrumental in explaining violence toward women in general and have contributed significantly to the understanding of animal abuse: patriarchy led dominant males to use violence as a means to control weaker beings, including other animals. Radical feminist Adams expresses this "as a hierarchy in which men have power over women, (feminized) men and (feminized) animals" (Adams, 1994, 80). Hence, from a feminist perspective, the abuse of animals is part of a larger dominance and exploitation by males of less powerful others-women, children, and animals (Flynn, 2012, 61).

\section{The Critics:}

"The Black Cat" allows for a multitude of interpretations. On the one hand, the story can be read as a tale of revenge, a tale of horror, a tale of the supernatural, an allegory for slavery, a critique of the criminal justice system, or as a self-portrait of Poe himself with the storyteller standing for the artist. Hammond in An Edgar Allan Poe Companion, informs that the cat was Poe's favorite animal and for some years a pet cat, Catarina, was a much-loved member of his household accompanying him on many errands. In "The Black Cat," Hammond reasons:

Poe was expressing his fear that his fits of temper might hurt those he cared for most in the world, Virginia and Maria Clemm, sober, he knew that he was courteous and refined at all times; he also knew that when in an alcoholic rage rationality deserted him. (Hammond, 1981, 82) Although Hammond's biographical reading is interesting, it seems far-fetched. In the words of Gargano, "Poe's narrators should not be construed as his mouthpieces" (Gargano, 1963, 
181). Nonetheless, a plethora of critics refuse to separate Poe from his creations viewing the artist and his narrators as identical "literary twins" (Gargano, 1963, 177). Poe's most sympathetic German interpreter Hanns Heinz Ewers is far more vocal than Gargano regarding this point when he declares, "He drank-he did not drink. That is the way the Anglo-Saxons dispute about their poets. . . . We [Germans] love him [Poe], even if he drank" (Ewers, 1978, 6, 8).

The few critics who did choose to separate the artist from his creations placed the story in its historical context. Joseph Stark, for example, argues that through "The Black Cat," Poe "upheld the mysterious nature of the human will in a time dominated by intellectual rationalism." The narrator's "motiveless frenzy," Stark proclaims, is Poe's statement "on the implications of prevailing scientific thought" (Stark, 2004, 255, 256). Matheson, however, regards the story as a commentary on nineteenth century abstinence claiming that in writing his tale Poe is contesting certain features of temperance literature (Matheson, 1986, 80). Even though the narrator is an alcoholic, states Matheson, alcohol cannot be blamed for his evil deeds given that evil can "exist independently, as an indelible part of human nature" (Matheson, 1986, 80). Alternatively, Hanrahan relates the story to domesticity and pet-keeping practices in Poe's America. She posits that in the mid-nineteenth century, pets were introduced into American homes as representations of reputable domesticity. "Good people-moral peopleowned pets, took good care of them, and taught their children to do the same." In contrast, immoral people, like Poe's narrator, practised acts of severe cruelty against animals, threatening the very fabric of American society. She goes on to add that "a growing anti-cruelty discourse" flourished in the nineteenth century with thinkers maintaining that animal maltreatment "can no longer be easily dismissed" because it "indicated ... a troubled and perhaps damned soul that might draw ... punishment in the next life." "The Black Cat" is, therefore, Poe's commentary on the subject (Hanrahan, 2012, 46, 53). Hanrahan's reasoning, though significant, limits Poe's tale to a specific time period neglecting its relevance today. More importantly, she fails to view animal maltreatment as a sign of serious emotional distress that may escalate into extreme violence against humans.

Critics who chose not to view the story from the lens of nineteenth century thought centered their discussions on the narrator's state of mind. Symons, Ransome, and Buranelli insist that Poe's characters, in general, are "far from normality" (Buranelli, 1977, 73). Others of the same opinion include Aubrey, Womack, Bloom, Stark, Mollegaard, Elswick, and Piacentino who call the narrator "an untrustworthy and unreliable authority" (Piacentino, 1998, 153). However, declaring the narrator a madman is problematic as it implies that no actual motive exists, evidenced when Stark announces mid-way through his discussion that "no sufficiently clear cause for the narrator's murder of his wife and the cat may be found in the text" (Stark, 2004, 260). Symons similarly notes: "Nothing we see in [the] text . . . is enough to explain what the narrator does to Pluto and later to his wife" (Symons, 1978, 50).

It is unfortunate that critics neglected to see the many complex issues surrounding the protagonist's behavior by simply labelling him "insane" (Stark, 2004, 255). To quote Shulman, it would be wise for criticism to concentrate on "Poe's unusually specific and profound understanding of the processes of obsession, displacement, hatred, and selfhatred" (Shulman, 1970, 259). As a result, this study maintains that the speaker is rational and aware of his actions. He is not psychotic. He does not see visions or hear voices. Also, his 
story contains much logic, especially if perceived from the standpoint of real-life. During Poe's time, American newspapers were filled with reports of sensational crimes and murder trials that the artist found fascinating (Hammond, 1981, 91). For example, the brutal killing of a young girl in New York in 1842, led Poe to write "The Mystery of Marie Roget" (1842). He voiced his enthusiasm over the murder mystery in a letter to his friend J.E. Snodgrass:

The story is based upon that of the real murder of Mary Cecilia Rogers, which created so vast an excitement some months ago in New York. I have handled the design in a very singular and entirely novel manner. . . . In fact, I really believe, not only that I have demonstrated the falsity of the idea that the girl was the victim of a gang, but have indicated the assassin. My main object, however . . is the analysis of the principles of investigation in cases of like character. (qtd. in Hammond, 1981, 93-94)

Hammond applauds the artist for choosing to investigate a real crime under the guise of fiction, "a courageous thing to do at any time but especially in the America of the 1840s" (Hammond, 1981, 95). While "The Black Cat" was not inspired by an actual murder, it shows Poe's incredible insight of genius anticipating in advance the discoveries of science. The speaker psychologically identifies the cat with his spouse, therefore, takes out his frustration on the innocent creature, ultimately killing it. Only then does he muster up enough courage to kill his intimate partner-the actual object of his contempt. The story is intelligible if understood in terms of animal abuse as an unfavourable prognostic sign characteristic of those who will commit homicide.

\section{The Protagonist:}

Poe's protagonist admits that he "made no scruple of maltreating the rabbits, the monkey, or even the dog, when by accident, or through affection, they came in [his] way." His violence escalates when one day he approaches his cat, Pluto, grasps it by the throat, and with a knife, gouges its eye out (Poe, 1843, 532). He then follows with an even more sinister act: "One morning, in cool blood, I slipped a noose about its neck and hung it to the limb of a tree" (Poe, 1843, 533). Although he had no adequate motive for killing Pluto, he nonetheless blames it on the "spirit of PERVERSENESS" (Poe, 1843, 533). This is not believable; the narrator evidently suffers from deep emotion and resentment: it is a cry of despair in which the bottled-up resentment finds expression in torturing and killing animals and ultimately humans.

Interestingly, in "Psychotic Perceptions of Pet Animals in Defendants Accused of Violent Crimes," forensic psychiatrist Felthous mentions Poe's "The Black Cat" as an exemplar of a fictional character who commits homicide due to his "psychotic perceptions of animals" (Felthous, 1984, 123). He calls the narrator an "insane subject" and proceeds to discuss three real-life cases of men whose paranoid delusions regarding their pets drove them to murder their wives (Felthous, 1984, 123).

Felthous' observation, though insightful, does not seem to apply to Poe's narrator, who appears fully aware of his wrongdoings. Nowhere in the story does he mention acting on command hallucinations from a cat or any other animal for that matter. The only time his view of reality distorts is when he fancies the white fur on the chest of the second cat morph into the shape of the gallows. This misrepresentation of reality can easily be attributed to his alcohol abuse playing havoc with his imagination, rather than a psychotic episode. Furthermore, Poe's protagonist, unlike the men Felthous discusses, is not isolated. On the contrary, he proves socially 
competent. He frequents local pubs, converses with his neighbours, and narrates his tale with much confidence. Accordingly, the killings of Pluto, and later of his wife, in no way exemplify psychotic homicide.

While not mad, Poe's narrator suffers nonetheless from psychological problems. In "The Abuse of Animals and Domestic Violence: A National Survey of Shelters for Women Who Are Battered," developmental psychologist Ascione and colleagues state that cruelty in any form "has long been considered a sign of psychological disturbance" (Ascione, Weber, Wood, 1997, 205). The speaker in "The Black Cat" provides a vivid description of Pluto's victimization, leaving no confusion whether the animal was being teased or severely brutalized and killed. His behavior is consistent with animal cruelty, as defined by the experts.

\section{Animal Cruelty:}

Psychiatrists Hellman and Blackman are in consensus that "cruelty to animals was positive if the subject reported killing or torturing dogs, cats, pets or baby animals" (Hellman and Blackman, 1966, 263). Ascione and colleagues define animal abuse as "socially unacceptable behavior that intentionally causes unnecessary pain, suffering, or distress to and/or death of an animal" (Ascione, Weber, Wood, 1997, 206). In "Childhood Cruelty to Animals and Later Aggression against People," Felthous and environmentalist Kellert describe it "as a pattern of deliberately, repeatedly, and unnecessarily hurting animals in a manner likely to cause serious injury" (Felthous and Kellert, 1987, 715). While animal rights activist Brown outlines abuse as "unnecessary suffering knowingly inflicted on a sentient being" (Brown, 1988, 3). Agnew, a criminologist, terms violence against animals as "any act that contributes to the pain or death of an animal or that otherwise threatens the welfare of an animal" (Agnew, 1998, 179). Aggressive acts, research indicates, include skinning, cutting, and setting fire to these small creatures to make the animals suffer (Merz-Perez, 2004, 120). It must be stressed, however, that animal cruelty is hardly ever "related to psychosis, mental retardation, or alcohol abuse" (Schlesinger, 2000, 325). Instead, it is linked to psychological problems. Motives for Animal Abuse:

In their published article entitled "The Tangled Web of Animal Abuse: The Links between Cruelty to Animals and Human Violence," animal rights activist Lockwood and psychiatrist Hodge provide one of the first scientific studies that examine the motives behind animal abuse in violent men. Their findings are based on a survey conducted on several groups of aggressive men who had repeatedly tortured animals:

Some resorted to cruelty to control an animal's behavior, for example, using beatings and electric prods to gain compliance from dogs. Many of the men used violence as a form of retaliation. One burned a cat that had scratched him, and another drowned a dog that barked too much. A third motivation was prejudice. Many abusers harbor hatred for specific animals. Cats were victims because they were often seen as "sneaky" and "creepy." Additional motives include, a desire to shock other people or to impress them with the abuser's capacity for violence. In some cases, cruelty to animals was used to retaliate against others. (Lockwood and Hodge, 1986, 80)

Poe's protagonist resorts to animal cruelty for a number of reasons. For example, he attacks Pluto when he fancies that "the cat avoided [his] presence" (Poe, 1843, 532). Leading him to retaliate:

I seized him; when, in his fright at my violence, he inflicted a slight wound upon my hand with his teeth. The fury of a demon instantly possessed me. . . I took from my waistcoat-pocket a pen-knife, 
opened it, grasped the poor beast by the throat, and deliberately cut one of its eyes from the socket! (Poe, 1843, 532)

At first, it looks as if the narrator punishes Pluto for injuring him, but as the story unfolds another more convincing reason emerges for targeting cats specifically-he subconsciously hates them. This animosity manifests itself in his use of words such as "irritation," "dislike," "disgust," "annoyance," "bitterness," "hatred," and "loathing," when referring to Pluto and the second cat (Poe, 1843, 532, 534). His abhorrence of cats ultimately reaches a breaking point when he kills Pluto and later fantasizes about destroying the second cat, "with a blow" (Poe, 1843, 535).

A further motive for his animal maltreatment could very well be "a desire to shock other people," mainly, his wife (Lockwood and Hodge, 1986, 80). This reason, according to Adams, is common with wife-batterers. In fact, the relationship between animal brutality and women is the subject of an insightful study by the radical feminist, who calls the link "the womananimal abuse connection." Adams replaces the term "companion animals," which is frequently used to describe domestic animals that are a part of the household, with the word "pet." The word is relevant in such a context as it shows the association "between sexualized behaviour and animals: the term 'pet' also connotes sexual activity, specifically fondling and caressing" (Adams, 1994, 64).

In "The Black Cat," the narrator's terminology regarding his pets is consistent with what Adams claims. He says that he spent most of his time "caressing" his "great variety of pets." Of his relationship with Pluto in particular he says, "Pluto . . . was my favorite pet and playmate" (Poe, 1843, 531). Moreover, when he encounters the second cat for the first time, he touches, pats, and caresses it (Poe, $1843,534)$. This in no way suggests that he was indulging in acts of bestiality with the creatures; however, it does imply that in his warped psyche animals (especially cats) and his wife are interchangeable. When he says, "I suffered myself to use intemperate language to my wife. At length, I even offered her personal violence," he immediately follows with, "My pets, of course, were made to feel the change in my disposition. I not only neglected, but illused them" (Poe, 1843, 532). Hence, his intimate partner is equated with the animals. Such degradation allows him to treat her in the same manner he treats his pets.

For Poe's narrator, allowing his wife to witness acts of meanness could be his way of showing her that he is in control given that she too is subjected to verbal and physical abuse, a point Adams verifies declaring: "Threats and abuse of pets by a woman's sexual partner occur in his attempts to establish control" (Adams, 1994, 65). Sociologist Piper also believes that one of the main reasons men harm animals is "to control their intimate female partners" (Piper, 2003, 164). It is their way of demonstrating masculinity (Flynn, 2012, 5). And psychologist Ascione maintains, "Abuse of pets may be a method batterers use to demonstrate virility" (Ascione, 1998, 119). Literary critic Bliss shares this point of view. In her article entitled "Household Horror: Domestic Masculinity in Poe's 'The Black Cat," Bliss explores Poe's tale "through the lens of gender construction," suggesting that the narrator abuses animals to establish his masculinity (Bliss, 2009, 96). Accordingly, maleness, dominance, control, revenge, and aggression appear to be behind the narrator's acts of cruelty toward animals. Poe's story therefore has significant implications for feminist philosophy and politics.

Poe's narrator obtains the height of satisfaction from torturing animals. He enjoys having absolute power and uses violence to sustain this supremacy. More importantly, he 
is indirectly showing his partner that he is in command. To understand his pathology is to understand the underlying psychology of a cold-blooded killer. The first act of cruelty produces little guilt. However, it is also like a dose of an addictive drug. He wants more. This in turn leads him to adopt a stray cat similar in appearance to Pluto, the cat he once loved but killed. After a while, the urge to kill returns and he finds himself unable to contain his compulsion. In a frenzied state, the narrator, aiming for the cat murders his wife instead (his intended victim no doubt). The killing of the first cat and that of his wife prove parallel acts.

\section{Motives for Targeting Cats:}

In Animal Cruelty: Pathway to Violence against People, animal cruelty investigative officer Merz-Perez stresses the importance of examining "the type of animal targeted" in cases of cruelty (Merz-Perez, 2004, 154). Schurman-Kauflin, a criminal profiler, shares this conviction arguing, "Most often, the deviant behavior is directed at cats, as they are easy targets and their absence is not as quickly noticed as dogs" (Schurman-Kauflin, 2000, 119). This is true to a certain degree. Nevertheless, cats are targeted more often than any other animal because they serve as surrogates for women, an opinion reinforced by sociologist Flynn who maintains that one of the functions of cats "[is] to serve as surrogate enemies" (Flynn, 2012, 14).

In a study conducted by criminologist Schlesinger on killers who had tortured cats; the subjects admitted "an intense dislike of this animal, in particular, but disclosed no insight into the animosity" (Schlesinger, 2000, 175). A real-life killer was quoted as saying, "I killed a cat once. I can't tell you why. I was just mad and the cat came at the wrong time and I strangled this cat." Another killer also confessed to targeting cats, "I got to tying a cherry bomb to the cat's leg, light it, and watch the cat run down the street. . . . I made a lot of one-legged cats" (Schlesinger, 2000, 222). Serial killer Ian Brady threw cats from windows just to watch them suffer. California serial killer Ed Kemper also enjoyed torturing cats: at thirteen he cut the family cat into pieces with a penknife (Wilson, 2007, 41). Hence, cruelty to cats appears in the backgrounds of many individuals who later commit homicide.

Cats are a female symbol more than other animals, and they arouse anger in the potential sex murderer (Schlesinger, 2000, 326). Vronsky, a crime expert, reported a case of a juvenile who gained much satisfaction from watching cats burn to death. He likened the felines to women, "observing similarities in their looks and behaviour" (Vronsky, 2004, 96). In "Psychosocial Aspects of Selecting Animal Species for Physical Abuse," Felthous and Kellert maintain that social attitudes toward certain animals, as well as, "idiosyncratic factors such as symbolic significance of the animal," play a pivotal role in an individual's choice of an animal to abuse (Felthous and Kellert, 1987, 1714). To support their theory, the authors conducted a study on incarcerated male subjects and found that impulsively aggressive men acknowledged cat hatred and cat cruelty and employed several methods for abuse. Some were so severe that they resulted in the feline's death:

Cats, even though domesticated, seem inscrutable and are therefore suitable for projection of unacceptable feelings. One subject likened his cat hatred to his prejudice against people of another race. Several subjects ... identified them as repositories of negative projections. Although none of the subjects identified cats as symbolic of evil women, a "bad mother," or the female genitalia, the possibility of consciously or unconsciously associating cats with women ought to be considered in aggressive men whose sexual and aggressive impulses may be 
fused at a primitive level, poorly differentiated, and poorly modulated. Although empirical evidence is scant ... cat hatred and abuse are associated with compulsive sexually motivated murderous attacks against women. (Felthous and Kellert, 1987, 1718-19)

Indeed, the link between cats and women in men prone to violence appears innate. Even French writer, philosopher, and theologian, Cavalier affirms that "cats have often been associated with women," above all in terms of their cunning and conniving. He further discloses, "The creature in general is regarded with a degree of mistrust" (Chevalier, 1994, 162-63).

\section{Motives for Targeting Black Cats:}

The color black also bears significant symbolism: Jung considered "black" to be the dark side of the personality, one allied with the female (Jung, 1981, 326). Black was the color of death; the color of all things dark, unknown, and often deadly; therefore, it was evil personified. By the Middle Ages when notions of witchcraft started running rampant, black cats began to be associated with everything bad. On this point, Potter states, "The black cat was believed to be the mascot or the familiar of witches; and as in the Norse legend, after seven years' service, to become a witch itself" (Potter, 1990, 29). Author of Cult of the Cat, Patricia Dale-Green elaborates:

Popular superstitions regarding cats identify these creatures as having evil influences. Numerous phrases attest to negative attitudes against cats. . . . Our country's European heritage recalls an era when cats were burned by the thousands because they were believed to be witches' familiars and vessels of the devil. (DaleGreen, 1963, 120)

Poe alludes to these superstitious beliefs in both his short essay "Instinct vs. Reason-A Black Cat" (1840) and in "The Black Cat," respectively. In the former, Poe first mentions his "remarkable" black cat and then remarks that "black cats are all of them witches" (Poe, $1840,65)$. In the latter, the narrator points out the association when he says: "My wife, who at heart was not a little tinctured with superstition, made frequent allusion to the ancient popular notion, which regarded all black cats as witches in disguise." After much hesitation, he adds, "and I mention the matter at all for no better reason than that it happens, just now, to be remembered" (Poe, 1843, 531). Although the narrator quickly dismisses the association, still it means something. In his warped psyche, cats, his wife, and witches are interlinked. For this reason, he centers his aggression on felines before moving on to murder his intimate partner. Cats seem to induce his sadistic projections and cruel behavior. The acts of violence directed toward cats prove actual attempts to hurt his intimate partner. In other words, cats serve as a receptacle for the anger directed at his wife.

\section{Uxoricide:}

The narrator's senseless killing of his "uncomplaining wife" has elicited much critical controversy (Poe, 1843, 536). Aubrey calls her an "enabler," who brought both abuse and murder upon herself by provoking her killer: "[I]t is his wife who keeps pointing out to him the patch of white fur on the cat's chest, where he eventually sees the portrayal of the gallows." This taunting, Aubrey suggests, "terrorizes the terrorist" and ultimately leads to his retaliation through murder (Aubrey, 2008, 38). Reeder theorizes that the narrator killed his wife because he viewed her as an extension of the self, and so wanted to rid himself of the feminine aspect of his anima (Reeder, 1974, 21). Piacentino considers the motive "to be subconscious and, therefore, the crime is not consciously premeditated. Nor is the narrator able to understand rationally or to persuade convincingly why he has done this terrible 
deed, though he repeatedly offers explanations" (Piacentino, 1998, 153). While Amper rightly reasons that the speaker has problems with intimacy and so targets cats because they serve as stand-ins for his wife (Amper, 1992, 475), a conviction shared by Crisman, Hoffman, Shulman, and Peeples who maintain the wife was killed because her "nature" bears "a striking resemblance to that of the cat's" (Shelden, 1976, 79). Despite the credibility of such reasoning, no motive is given for uxoricide, nor is animal abuse viewed in relation to interpersonal violence.

\section{Causes of Deviant Behavior:}

Before someone can understand the mindset of those who commit acts of murder, it is essential to examine those factors that form a continuum throughout the individual's life (Holmes, 1988, 79). What causes deviant behavior? For the narrator/protagonist of Poe's "The Black Cat," the primary impetus to homicide stems from the profound need to exert power and control; to exercise absolute and unquestioned dominance over another human being. Literary critic Halliburton fittingly calls the story "a domestic tragedy," in which the first-person "dwells on the domestic nature of his story: it is a 'most homely narrative' which he pens, a series of mere household events." He adds, "So long as the others, pets or persons, do not transcend the 'property' relation, or resist his 'territorial imperative,' they are safe from the protagonist's wrath. However, once they assert themselves they are immediately imperiled" (Halliburton, 1973, 343-44). Though Halliburton's argument is worth noting, the psychodynamics and developmental history of such a killer is far more intricate.

The social history of Poe's protagonist particularly his early relationship with his family is essential to understanding his story. He asserts from the very beginning that his parents spoiled him: "[I] was indulged by my parents with a great variety of pets" (Poe,
1843, 531). Such treatment gave the young narrator the idea that he was special and should receive special attention and abide by a different set of rules than everyone else. This pampering from such an early age leads to a strong sense of entitlement. Naturally, over time, his sense of entitlement warps his view of the world.

In Till Death Do Us Part: Love, Marriage, and the Mind of the Killer Spouse, Psychotherapist Ludwig explains that the overindulged personality makes it very difficult to tolerate frustration. The psychotherapist elaborates with: "Criminals tend to have two extreme family dynamics; either they were terribly abused as children and therefore feel entitled to whatever they can take in later life, or they were overly indulged, giving them the idea that they deserve whatever they desire" (Ludwig, 2006, 120-121). In the case of the spoiled child, he "is really dehumanized and instrumentalized" (Ludwig, 2006, 121). This "dehumanization" leads to much antipathy causing the indulged child to act-out. Ultimately he grows into an egocentric, proud, and pompous adult, which is what presumably happened to Poe's narrator. The reader is introduced very early in the story to a case history of a classic narcissist.

The narrator is self-absorbed, egocentric, and proud of his criminal acts to the extent of being a braggart. His behavior typifies the narcissist, who according to Ludwig, "rarely converses, but often lectures" (Ludwig, 2006, 104). His narcissism manifests itself further through the pride he shows in being "fashioned in the image of the High God" (Poe, 1843, 535). This opinion is shared by Halliburton who also perceives the narrator as haughty and proud, writing: "Where other murderers have secret stores of guilt, the murderer of the cat has stores of pride. As psychologists remind us, the man who takes another's life is sometimes an exhibitionist whose act is not completed until he witnesses its 
acknowledgement by others; thus his urge to confess" (Halliburton, 1973, 346). Indeed, the narrator relishes the fact that he has murdered his wife. For him, it is one of his greatest achievements. Precisely for this reason, he confesses his crime.

\section{Motivation for Murder:}

According to criminologist Leibman homicide occurs when "the ego-protective mechanisms, previously used successfully, fail, and the individual then acts out in a violent manner." She continues, "This is particularly true when the person feels threatened or frustrated. Complicating this problem may be situations or people that predispose the murderer to frustrated or angry reactions" (Leibman, 1989, 236). Poe's narrator describes himself as a man once well known for his compassion. He was "especially fond of animals." He loved and cared for them, "and never was so happy as when feeding and caressing them." When he decides to marry, he selects a partner who shares his affection for pets. His home is soon filled with a variety of creatures. He becomes especially fond of one pet, Pluto, "a remarkably large and beautiful animal, entirely black, and sagacious to an astonishing degree" (Poe, 1843, 531). At first, all seems well with the narrator. However, as his alcohol intake increases and his inhibitions diminish, his real personality emerges: he becomes tyrannical to the extreme. His "ego-protective mechanisms" seem to collapse once he settles into married life. From then on, cats and his wife become threatening agents bent on reminding him of his inadequacy.

Leibman provides further insight into homicide: "There are three primary psychological elements contributing to motivation for murder: frustration, fear, and depression," which can arouse the urge to kill (Leibman, 1989, 236). In "The Black Cat," the narrator displays all three. To begin with, he appears frustrated with cats, creatures that cause him great distress. He also experiences fear, especially after the fire, when he sees a figure of a cat form on the newly plastered wall and recalls "My terror was extreme." Adding, "For months I could not rid myself of the phantasm of the cat" (Poe, 1843, 532).

Apart from Pluto, the second cat too begins to terrify him, and he grows to "dread ... the beast." He describes his feelings as those of "terror and horror," and later admits, "I loathed, and dreaded, and would have rid myself of the monster had I dared" (Poe, 1843, 532, 533, 535). As to depression, Leibman's third psychological element, this also manifests itself in his character, especially when he complains that "neither by day nor by night" did he know "the blessing of Rest anymore!" (Poe, 1843, 535).

Ludwig states, "Murder doesn't just happen out of nowhere. People don't just snap without any warning signs. There are always signs" (Ludwig, 2006, 198). In the case of Poe's narrator, his problem appears to be a deepseated hatred of women. This point is echoed by Halliburton, who comments, "The story depicts a central consciousness that expresses itself in the first person, and that finds itself confronted with and in some way challenged by the presence of a woman" (Halliburton, 1973 , 97). From the very beginning, the speaker shows a fixation with his wife that borders on obsession. He mentions her ten times in the short tale, starting with, "I married young, and was happy to find in my wife a disposition not uncongenial with my own," mentioning her again when Pluto is introduced into the story, and once more when he admits to abusing her. When he alludes to the night of the fire, he says, "It was with great difficulty that my wife, a servant, and myself, made our escape." Later when he brings home the stray cat, he says of the incident "[it] domesticated itself at once, and became a great favorite with my wife," and the fact that it had one eye 
missing "only endeared my wife." He proceeds with, "My wife had called my attention ... to the character of the mark of white hair . . . which constituted the sole visible difference between the strange beast and the one I had destroyed." His intimate partner is brought up again when he says, "my uncomplaining wife, alas! was the most usual and the most patient of sufferers." And finally, "Uplifting an axe . . . I aimed a blow at the animal. . . . But this blow was arrested by the hand of my wife. Goaded, by the interference, into a rage more than demoniacal, I withdrew my arm from her grasp and buried the axe in her brain. She fell dead upon the spot, without a groan." It is important to note here that once the murder is committed, he ceases to refer to his intimate partner as his wife, and calls her "the corpse" instead (Poe, 1843, 531-538). Whether he does this consciously or subconsciously is unknown. Still, it shows a desire on his part to completely obliterate her identity.

Ludwig continues to theorize: "MANY murders [of spouses] are motivated by revenge, a very common yet noxious desire for retribution" (Ludwig, 2006, 151). Vronsky too notes that revenge is the primary motive for homicide, particularly in cases where the killer uses excessive violence to kill his victim (who is usually female). He elaborates:

The primary motive driving the killer is his need to avenge, get even with, or retaliate against a female, or her substitute, who somehow offended the killer in his perception. The rage is often inspired by a female with power presently or in the past over the offender-his mother, his wife ... the rage is triggered when either the same female or another, in his perception, criticizes, scolds, humiliates, rejects, belittles, or somehow disrespects him.

(Vronsky, 2004, 205)

For the narrator in Poe's tale, it is evidently clear that he reached a state where his emotions became unbearably torturous. In the heat of a moment of uncontrollable anger and rage, he butchered his wife with an axe. His vicious attack on his partner demonstrates his attempt to wipe away her gender. It is possible that in subjecting her to a frenzied attack, he was trying to annihilate her, to de-sex her, so that she was no longer a threatening woman. He even conceals her corpse behind the cellar wall to further degrade her.

\section{The Narrator's Animosity Towards Women:}

Women are objects of the greatest contempt for the narrator. Although his confession points to this abhorrence, he shows no conscious awareness of it. His disgust with the female sex is subconscious. Therefore, the murder is a purely violent and vindictive act that stems from inadequacy. Even though he suppresses such feelings, they manage to transpire through his words and actions. A clear example is his assertion, "There is something in the unselfish and self-sacrificing love of a brute, which goes directly to the heart of him who has had frequent occasion to test the paltry friendship and gossamer fidelity of mere Man" (Poe, 1843, 531). He reveals here that he suffered rejection in the past (presumably by a woman); for this reason, the company of animals is preferred. Animals are "unselfish," "self-sacrificing," and "loyal"unlike women. Nonetheless, as soon as he begins to identify cats with the female gender his perception of the creatures becomes one of beings that frighten and repel; evident in his reference to "witches" (Poe, 1843, 531).

In "The Threat to Kill" psychiatrist MacDonald lists pathological jealousy "ranging from baseless mistrust to frank paranoid delusions," as contributing significantly to "threats to kill." MacDonald maintains, "Suspicions of marital infidelity, present throughout the marriage might reach delusional proportion following business reverse, loss of job, the onset of physical illness, impotence, or organic brain disease" 
(MacDonald, 1963, 127). In "The Black Cat," the protagonist is jobless. Moreover, his sole interest appears to be frequenting "den[s] of more than infamy," and drinking heavily (Poe, 1843 , 534). Both factors, coupled with a past snub, can result in pathological jealousy, especially if he is impotent too. This last point is very likely given his alcoholism. Schlesinger, in fact, knows alcohol to be a common cause of erectile dysfunction. He explains, "Alcohol is a depressant, and using it heavily can worsen mood, decrease sexual desire, and make it difficult for a man to achieve erections or reach an orgasm while under the influence" (Schlesinger, 2000, 59). Sociologist Falk also claims that alcohol and other drugs "do indeed constitute one of the conditions of erectile dysfunction" (Falk, 1990, 45).

In the story, there is no mention of offspring, only pets, suggesting that there is something wrong with the narrator. Hence, his inability to physically indulge his spouse must have led him to question his partner's fidelity. His behavior proves analogous to actual reallife murderers who "look around for someone on whom to lay the blame" (Wilson, 2007, 21). Poe's protagonist most likely blinded himself to the idea that he might be responsible for his problems. Consequently, feeling inferior and helpless his self-esteem quickly diminished. Such intense suffering can lead to an unyielding desire to retaliate. It can turn dangerously violent. Interestingly enough, Bliss too seems to have picked up on the narrator's inadequacy, remarking:

While the narrator's marriage

conventionally establishes his masculinity, he fails to fully inhabit the role of husband. The story spans several years, but the couple has no children, nor does the narrator appear to be employed. Both childlessness and joblessness indicate the narrator's inability to meet biologically and culturally determined gender

expectations. (Bliss, 2009, 97)

While Bliss' statement corresponds with this study's line of reasoning, her later claim that the narrator's acts of violence are an attempt to conceal "the feminine aspects of his identity" seems unlikely. Also unlikely is calling Pluto "his surrogate child" who gets killed because "the cat sees through the façade of benign masculinity . . . into the reality of the narrator's failed manhood" (Bliss, 2009, 97). In truth, cats have little to do with the narrator's troubles given that it is usually women who are blamed for "failed $\operatorname{manhood}[\mathrm{s}]$," not felines, a point Bliss completely dismisses.

\section{Murder as a Form of Release:}

Once dead, the wife delivers her husband to an awful freedom. He even refers to the act of murder as an act of accomplishment, when he triumphantly announces: "This hideous murder accomplished, I set myself forthwith, and with entire deliberation, to the task of concealing the body." Following with, "I looked around triumphantly, and said to myself-'Here at least, then, my labor has not been in vain'" (Poe, 1843, 537). There is no sense of guilt or remorse. He is not horrified afterwards. Instead, he boasts that he slept peacefully that night, "I soundly and tranquilly slept; aye, slept even with the burden of murder upon my soul!" (Poe, 1843, 537). This is because he has been harboring intense anger and deep feelings of inadequacy for quite some time. To have that released in a violent act is cathartic.

Freud perceived intimate relationships as unsustainable. He thought it was impossible to have a bond that lasted for any length of time without some residue of hostility or dislike. Ludwig supports this point, proclaiming "For most people involved in relationships, who initially tend to idealize their partner, these negative feelings become repressed, and the repression helps them feel less angry with their 
partners" (Ludwig, 2006, xix). In the case of the narrator, his resentment could no longer be contained. It had to find an outlet, and murder became the only solution.

"Murder is a power trip"; many murders are an effort "to compensate the killer for his belief that he has no power" (Falk, 1990, 91). For the narrator, killing his wife gave him a sense of control, a feeling of power. He was somebody at last rather than an insignificant nobody. The rewards of the homicide prove plentiful for him. This perhaps explains why he did not just divorce his wife, since divorce would not have satisfied his need to exact revenge or enforce his self-image. Being a narcissist, the narrator expects complete adulation from those around him, above all, his intimate partner. However, imagining that his spouse was no longer the adoring, docile, and obedient wife he once knew, he could no longer settle for a person who failed to recognize his uniqueness in the world. Filled with bitterness at the apparent failure of his life, he took his revenge.

\section{Conclusion:}

To conclude, this study examined animal cruelty and its association to intimate partner homicide in Poe's "The Black Cat." The study proved that power engrosses Poe's narrator. His violent acts towards both animals and human[s] are about the sadistic exercise of authority and control over others, specifically females. He does not merely harm the animals but tortures them; he does not just inflict suffering but does so literally in a hands-on manner, and the same applies to his wife-a woman. Merz-Perez states of future offenders, "If killing animals made them feel good, the next logical step for further gratification was humans," a point that undoubtedly applies to the narrator (Merz-Perez, 2004, 37). If ever released, he is likely to kill again because killing gives him a sense of accomplishment. It makes him feel powerful and potent. The story is perhaps of most interest today as a case study of a particular type of criminal mentality, that of a man who feels inferior.

In Shelley's Frankenstein, the creature spews out, "I am malicious because I am miserable. . . . Am I not shunned and hated by all mankind? You, my creator, would tear me to pieces - why should I pity man more than man pities me? I will revenge my injuries: If I cannot inspire love, I will cause fear" (Shelley, 1989, 119). The narrator of "The Black Cat" similarly spews, "The moodiness of my usual temper increased to hatred of all things and of all mankind" (Poe, 1843, 536). Criminologists use this linkage of misery and "acting out" to demonstrate why criminals harm others. "The Black Cat" thus adheres to the new dynamic of psychology, criminology, and physical research. More importantly, the story raises awareness to animal cruelty as a precursor to future violence against humans, particularly women.

\section{References}

Adams, Carol J. (1994), "Bringing Peace

Home: A Feminist Philosophical

Perspective on the Abuse of Women,

Children, and Pet Animals", Hypatia, 9, 6384.

Agnew, Robert (1998), "The Causes of

Animal Abuse: A Social-Psychological

Analysis", Theoretical Criminology, 2, 177209.

Amper, Susan (1992), "Untold Story: The

Lying Narrator in 'The Black Cat'", Studies in Short Fiction, 29 (4), 475-85.

Ascione, Frank R., Claudia Weber and David Wood (1997), "The Abuse of Animals and Domestic Violence: A National Survey of Shelters for Women Who Are Battered", Society \& Animals, 5, 205-18.

Ascione, Frank R. (1998), “Battered Woman's Reports of Their Partners' and Their Children's Cruelty to Animals", Journal of Emotional Abuse, 1(1), 119-33.

Aubrey, Bryan (2008) "Critical Essay on 'The Black Cat"' in Ira Milne, ed. (2008), Short 
Stories for Students, California: Sage, 3538.

Bliss, Ann (2009), "Household Horror: Domestic Masculinity in Poe's 'The Black Cat'", The Explicator, 67 (2), 96-99. Web. 14 Oct. 2017.

Brown, Les, (1988) Cruelty to Animals: The Moral Debt, London: Macmillan.

Buranelli, Vincent, (1977) Edgar Allan Poe. $2^{\text {nd }}$ ed. Boston: Twayne.

Chevalier, Jean and Alain Gheerbrant (1994) A Dictionary of Symbols, Trans. John Baouchnan-Brown. $2^{\text {nd }}$ ed. London: Blackwell.

Crisman, William (1984), “"Mere Household Events' in Poe's 'The Black Cat'", Studies in American Fiction, 12, 87-90.

Dale-Green, Patricia, (1963) Cult of the Cat, Boston: The Riverside Press.

Elswick, Morgan E. (2015), "The Unspeakable: Fearing Madness in Poe's 'The Black Cat'", The Downtown Review, 2 (2), 1-6.

Ewers, Hanns Heinz, (1978) Edgar Allan Poe, Trans. Adele Lewisohn. New York: Norwood.

Falk, Gerhard, (1990) Murder: An Analysis of Its Forms, Conditions, and Causes, Jefferson: McFarland \& Company.

Felthous, Alan R. (1980) "Aggression against Cats, Dogs and People" in Randall Lockwood and Frank Ascione, eds. (1998), Cruelty to Animals and Interpersonal Violence, West Lafayette: Purdue University Press, 159-167.

Felthous, Alan and Stephen Kellert (1987), "Childhood Cruelty to Animals and Later Aggression against People: A Review", American Journal of Psychiatry, 144, 71017.

Felthous, Alan and Stephen Kellert (1987), "Psychosocial Aspects of Selecting Animal Species for Physical Abuse", Journal of Forensic Sciences, 32 (6), 1713-23.
Felthous, Alan and Stephen Kellert (1984) "Psychotic Perceptions of Pet Animals in Defendants Accused of Violent Crimes" in Randall Lockwood and Frank Ascione, eds. (1998), Cruelty to Animals and Interpersonal Violence, West Lafayette: Purdue University Press, 123-131.

Flynn, P. Clifton, (2012) Understanding Animal Abuse: A Sociological Analysis, New York: Lantern.

Gargano, James (1963), "The Question of Poe's Narrators", College English, 25, 17781.

Halliburton, David, (1973) Edgar Allan Poe: A Phenomenological View, Princeton: Princeton University Press.

Hammond, J.R., (1981) An Edgar Allan Poe Companion, London: Macmillan Press.

Hanrahan, Heidi (2012), "'A Series of Mere Household Events': Poe's 'The Black Cat,' Domesticity, and Pet-Keeping in Nineteenth-Century America", Poe Studies, 45, 40-56.

Hellman, Daniel S. and Nathan Blackman (1966) "Enuresis, Firesetting, and Cruelty to Animals: A Triad Predictive of Adult Crime" in Randall Lockwood and Frank Ascione, eds. (1998), Cruelty to Animals and Interpersonal Violence, West Lafayette: Purdue University Press, 262-266.

Hoffman, Daniel, (1973) Poe Poe Poe Poe Poe Poe Poe, New York: Doubleday.

Holmes, Ronald M. and James De Burger (1988) Serial Murder, London: Sage.

Jung, Carl Gustav (1981) The Archetypes and the Collective Unconscious, Trans. R. F. C. Hull. $2^{\text {nd }}$ ed. Vol. 1. Princeton: Princeton University Press.

Leibman, Faith (1989) "Serial Murderers: Four Case Histories" in Randall Lockwood and Frank Ascione, eds. (1998), Cruelty to Animals and Interpersonal Violence, West Lafayette: Purdue University Press, 236240. 
Lockwood, Randall, and Frank R. Ascione, eds. (1988), Cruelty to Animals and Interpersonal Violence, West Lafayette: Purdue University Press.

Lockwood, Randall and Guy R. Hodge (1986) "The Tangled Web of Animal Abuse: The Links between Cruelty to Animals and Human Violence" in Randall Lockwood and Frank Ascione, eds. (1998), Cruelty to Animals and Interpersonal Violence, West Lafayette: Purdue University Press, 77-82.

Ludwig, Robi and Matt Birkbeck (2006) Till Death Do Us Part: Love, Marriage, and the Mind of the Killer Spouse, New York: Atria. MacDonald, John (1963), "The Threat to Kill", American Journal of Psychiatry, 120, 125130.

Matheson, T. J. (1986), "Poe’s 'The Black Cat' as a Critique of Temperance Literature", Mosaic, 19 (3), 69-81.

Merz-Perez, Linda, (2004) Animal Cruelty: Pathway to Violence against People, Lanham: Altamira Press.

Mollegaard, Kirsten (2014), “Animal Invasion: Estrangement and the Domestic Uncanny in Edgar Allan Poe's 'The Black Cat' and 'The Murders in the Rue Morgue", International Journal of Arts \& Sciences, 7 (5), 11-26.

Peeples, Scott, (1998) Edgar Allan Poe Revisited, Woodbridge: Twayne.

Piacentino, Ed (1998), "Poe's 'The Black Cat' as Psychobiography: Some Reflections on the Narratological Dynamics", Studies in Short Fiction, 35, 153-67.

Piper, Heather (2003), "The Linkage of Animal Abuse with Interpersonal Violence: A Sheep in Wolf's Clothing?", Journal of Social Work, 3, 161-77.

Poe, Edgar Allan (1843), "The Black Cat", in T.O. Mabbott, ed. (1951), The Selected Poetry and Prose of Edgar Allan Poe, New York: The Modern Library. 531-538.

Poe, Edgar Allan (1840), "Instinct vs. Reason-A Black Cat", in Raymond Foye, ed. (1980), The Unknown Poe: An
Anthology of Fugitive Writings of Edgar Allan Poe, San Francisco: City Lights. 6567.

Potter, Carole, (1990) Touch Wood: An Encyclopaedia of Superstition, London: Michael O'Mara.

Rae, George, (1967) The Official TapeRecorded Confessions of the Boston Strangler, New York: Pyramid Press.

Ransome, Arthur, (1972) Edgar Allan Poe: A Critical Study, New York: Haskell.

Reeder, Roberta (1974), "“The Black Cat' as a Study in Repression", Poe Studies, 7, 20-27.

Ressler, Robert, (1988) Sexual Homicide: Patterns and Motives, New York: Free Press.

Schlesinger, B. Louis, (2000) Sexual Murder: Catathymic and Compulsive Homicides, Boca Raton: CRC Press.

Schurman-Kauflin, Deborah, (2000) The New Predator: Women Who Kill, New York: Algora.

Shelden, Pamela (1976), “'True Originality”: Poe's Manipulation of the Gothic Tradition", American Transcendental Quarterly, 29, 75-80.

Shelley, Mary, (1989) Frankenstein, or the Modern Prometheus, 1818, New York: Tom Doherty.

Shulman, Robert (1970), "Poe and the Powers of the Mind", JSTOR, 37 (2), 245-62.

Stark, Joseph (2004), "Motive and Meaning: The Mystery of the Will in Poe's 'The Black Cat"”, Mississippi Quarterly, 57 (2), 255-59.

Symons, Julian, (1978) The Tell-Tale Heart: The Life and Works of Edgar Allan Poe, London: Faber \& Faber.

Vronsky, Peter, (2004) Serial Killers: The Method and Madness of Monsters, New York: Berkley.

Wilson, Colin, (2007) The Serial Killers: A Study in the Psychology of Violence, London: Virgin. 
العنف ضد الحيوان وقتل الثريكة في الأقصوصة الأدبية "القطة السوداء" للكاتب الأمريكي أدجار آلان بو أ.د. عفر اء الثيبيان

ملخص. أُعتبرت القسوة ضد الحيوان و علاقتها بالعنف ضد المر أهُ مجالاً خصباً لكل من عماء الجريمة، علماء

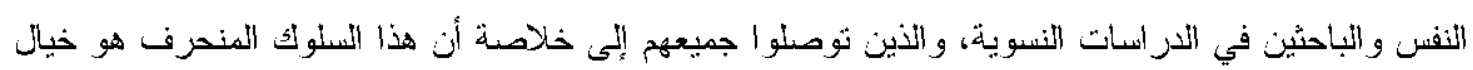

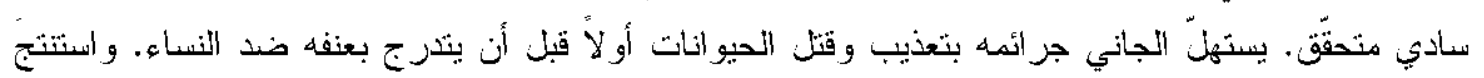

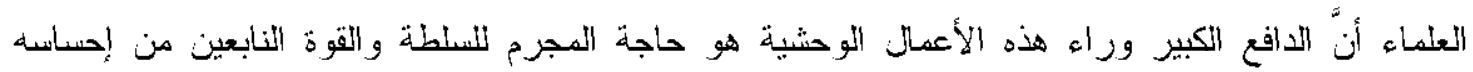

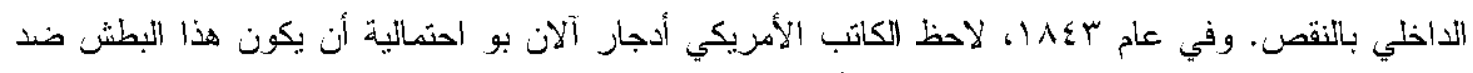

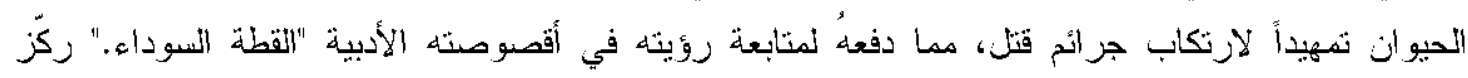
الترو ائي حبكة قصنه على جعل القطط بدائل للنساء، حنى استحضر الجاني ما يكفيه من الثجاعة لقتل زوجته. وقد سبق بو عصره بقصته القصبرة النتي سلطت الضوء على أن تعذيب الحيو انات ما هو إلاًّ نذير لسلوكيات

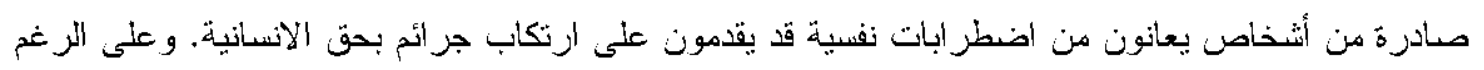

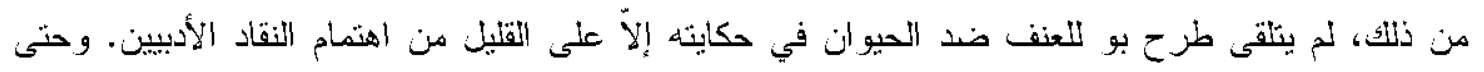

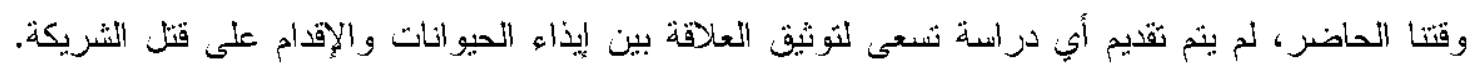
ولذلتك فإن هذه الدر استة

تقدم رؤية بحثية حديثة للقطعة الأدبية قد نضيف منظوراً علمياً إلىى موسوعة هذا الكاثب.

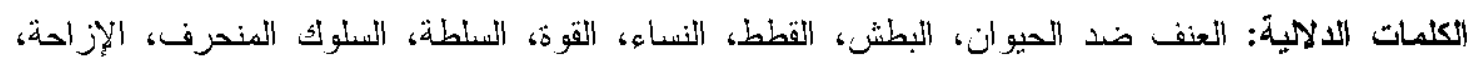
القتل 